\title{
New Insights Into Surface-Water/Groundwater Exchanges in the Guadalupe River, Texas, From Floating Geophysical Methods
}

In south-central Texas, the amount of streamflow in the Guadalupe River is a primary concern for local and downstream communities because of municipal, agricultural, wildlife, and recreational uses. Understanding the flow paths and rates of exchange between the surface water in the river and the groundwater in the underlying Carrizo-Wilcox aquifer is vital for understanding the water budget and streamflow variations. In areas where the Guadalupe River crosses the CarrizoWilcox aquifer outcrop, the surface-water and groundwater exchanges are not well characterized. Traditional methods to measure these interactions, such as measuring differences in surface-water flows at different locations to infer gains and losses between the locations, are not feasible along this stretch of the Guadalupe River because of upstream dams that cause large daily fluctuations in streamflow. Consequently, the

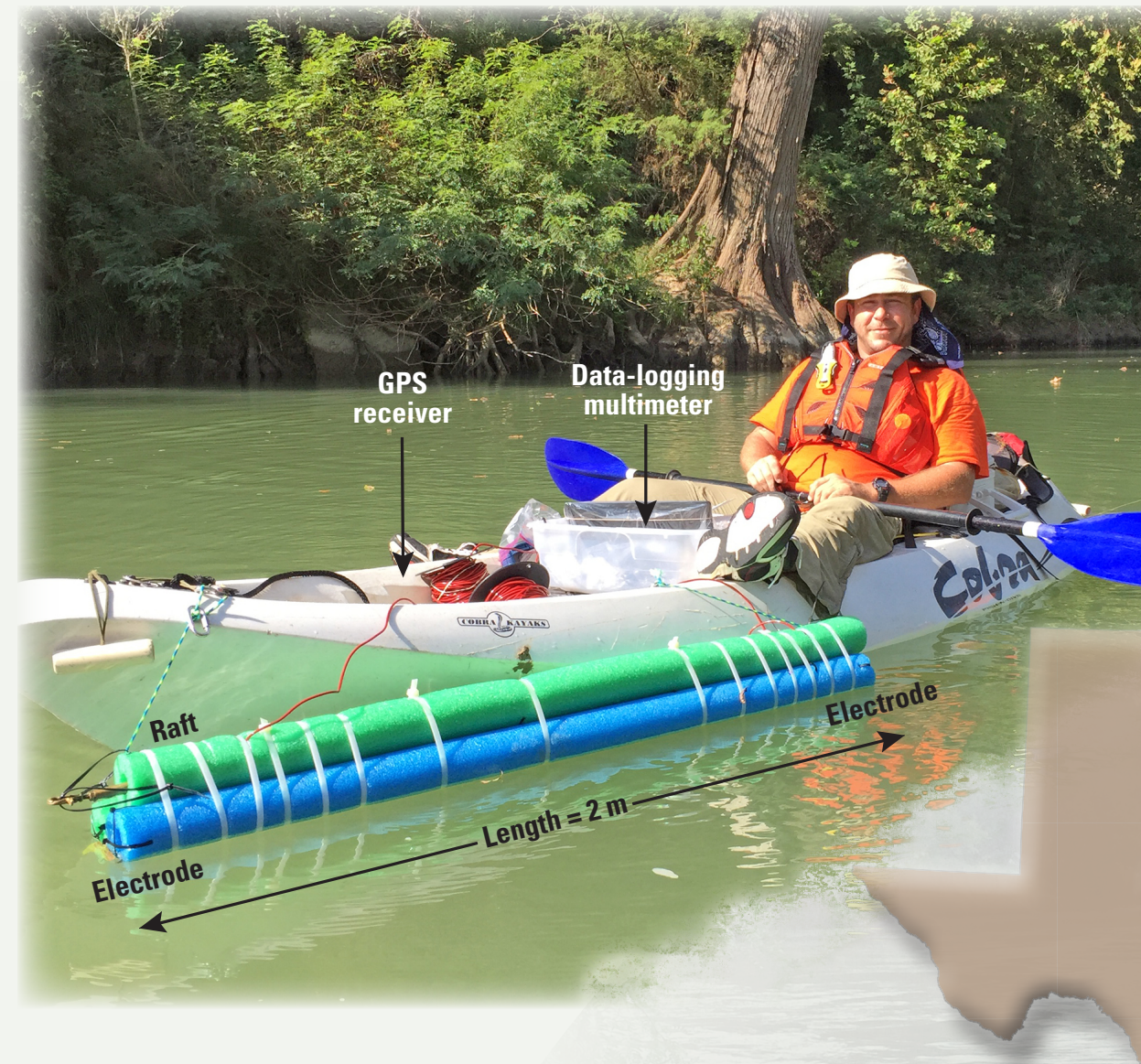

Figure 1. Geophysical measurement equipment and typical streamflow conditions in the Guadalupe River, south-central Texas, during the self-potential survey, September 2016. [GPS, Global Positioning System; m, meter. Photograph by C. Hartman, U.S. Geological Survey]
U.S. Geological Survey, in cooperation with the GuadalupeBlanco River Authority, applied geophysical methods in an exploratory study to identify reaches of the river where streamflow gains and losses (surface-water/groundwater exchanges) might be occurring.

\section{Electric Resistivity Tomography and Self-Potential Profiling}

The study integrated two geophysical methods-floating electric resistivity tomography (ERT) and floating gradient self-potential (SP) profiling (Ikard and others, 2018). These geophysical methods measured the voltages between two or more electrodes that were separated by fixed distances and submerged in the river near the water surface. The ERT and SP profiles were measured along approximately 15 kilometers of the Guadalupe River in 2016 by towing instruments behind a boat or attaching them to a kayak (fig. 1). These geophysical methods, signal processing procedures, and resulting datasets are described in detail in Ikard and others $(2017,2018)$. Voltages measured by ERT electrodes can be related to the subsurface geology and electrical resistivity (Reynolds, 1997; Griffiths, 1999), whereas voltages measured by SP electrodes can be related to water flowing through the geologic materials (Nyquist and Corry, 2002; Revil and others, 2017). 


\section{Summary of Findings}

The ERT profile identified differences in the subsurface hydraulic properties beneath the stream channel bed by mapping differences in electrical resistivity that likely correspond to locations of fine and coarse materials (Griffiths, 1999). In the upstream part of the study area, the ERT profile indicated that the Carrizo-Wilcox aquifer was present beneath a few meters of alluvium in the streambed, whereas the downstream part of the study area transitioned to more alluvium and channel sands (fig. 2). The shift in the ERT profile occurred approximately where the Carrizo-Wilcox aquifer transitions from an outcrop to a subcrop (in other words, is no longer present at the surface) and likely at the beginning of the Reklaw Formation (Baker, 1995).

Numerical modeling of the SP profile identified subreaches where surface-water/groundwater exchanges were likely occurring (figs. 2 and 3). Where the SP profile was positive, numerical modeling indicated that the SP profile represented a net gain of water to the stream at that location. Conversely, where the SP profile was negative, numerical modeling indicated that the SP profile represented a net loss of water from the stream into the alluvium and channel sands or into the deeper aquifer. The net gain or loss of streamflow in the river channel is most likely the result of a combination of both regional ambient groundwater exchange (where water flows to or from the regional aquifer) and localized hyporheic exchange flow (where water flows into and out of the alluvium and channel sands in the streambed and flood plain within relatively short distances).

The largest surface-water/groundwater interactions appeared to be occurring where the stream flows over the Carrizo-Wilcox aquifer outcrop. Specifically, the SP profile in the first kilometers of the study area (subreach 1) exhibited a strong negative signal (as much as approximately -70 millivolts $[\mathrm{mV}]$ ), indicative of downwelling of water into the subsurface (figs. 2 and 3). At the upstream portion of subreach 2, the SP profile switched to a strong positive signal (as much as approximately $+50 \mathrm{mV}$ ), indicative of upwelling of water coinciding with the Carrizo-Wilcox aquifer outcrop. The apparent upwelling of water to the stream lessened in subreach 3 (the SP signal was generally less than $+10 \mathrm{mV}$ ) as the channel becomes more dominated by alluvium and channel sands downstream. The SP profile was relatively neutral in subreach 3 and then increased again at the end of subreach 4 (as much as approximately $+30 \mathrm{mV}$ ), possibly indicating the transition into the Reklaw Formation, which is the next downstream hydrostratigraphic unit (Baker, 1995; George, 2011). Numerical modeling of the SP profile also indicated that at some reaches the surface-water/groundwater exchanges might be more influenced by regional ambient groundwater exchange flows, whereas at other reaches localized hyporheic exchange flows might be a larger contributor.
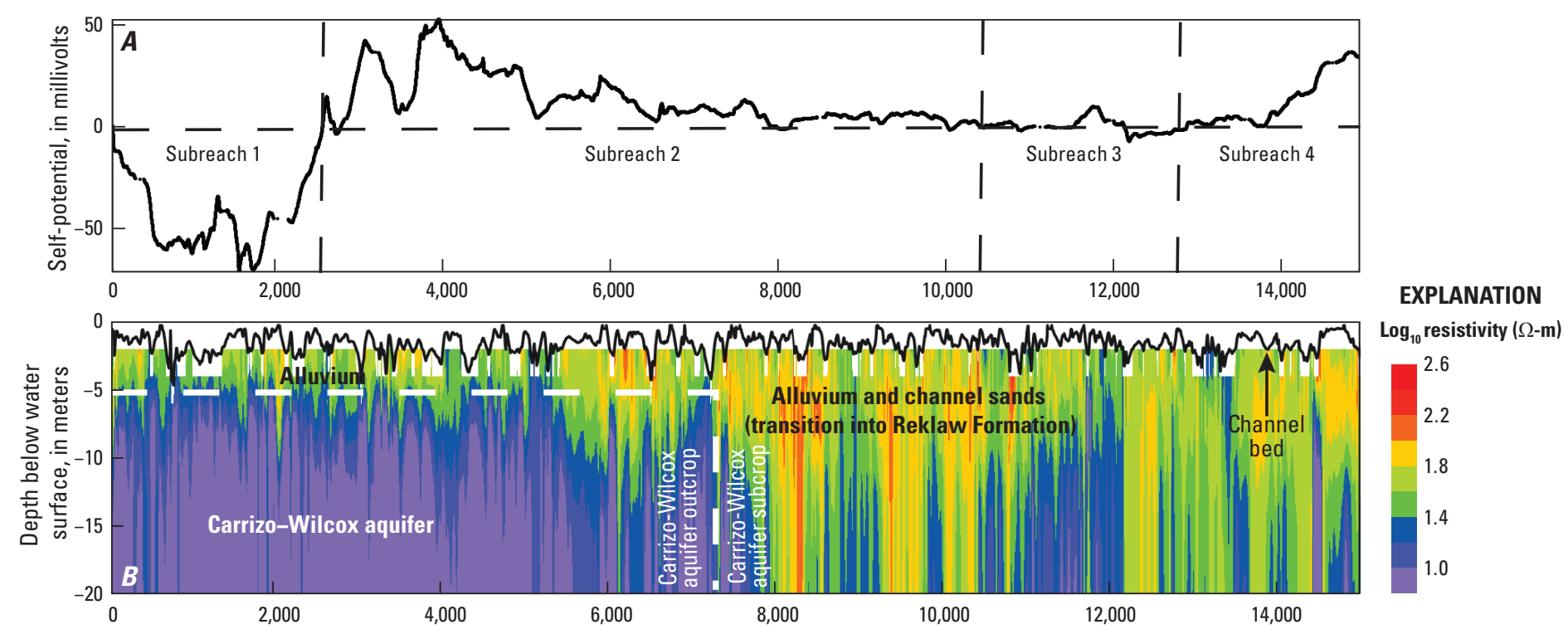

Upstream part of the study area

Profile distance, in meters

Downstream part of the study area

Figure 2. Self-potential (SP) and corresponding electric resistivity tomography (ERT) data collected along an approximately 15-kilometer reach of the Guadalupe River, south-central Texas. $A$, SP profile with identified subreaches. $B$, ERT profile showing a cross-sectional representation of the subsurface hydrogeology beneath the stream channel bed. 


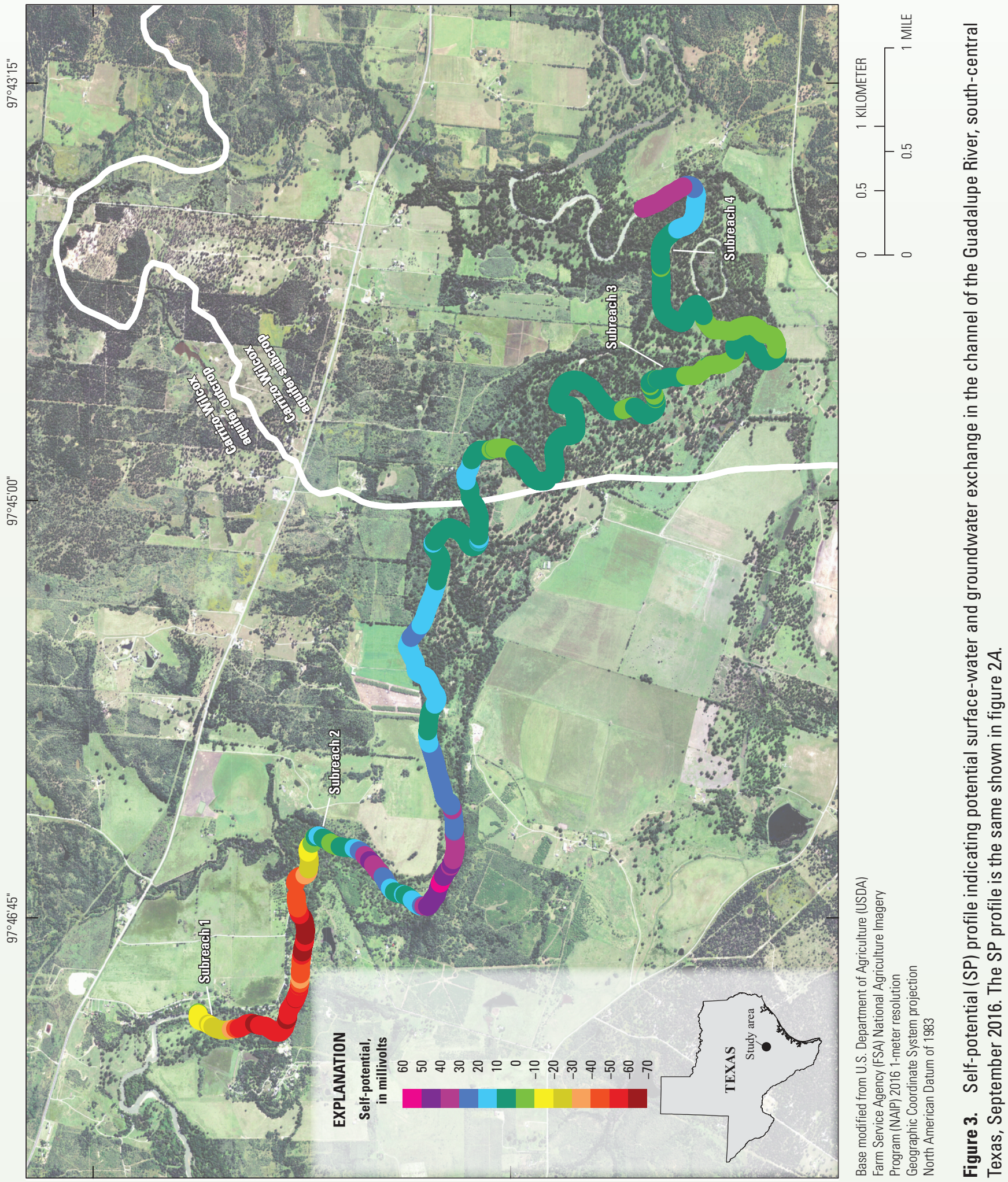


Understanding the dynamics of streamflow gains and losses and the hydrologic connectivity of the stream with the flood plain and underlying aquifers is important for water resource managers to make informed decisions regarding the Guadalupe River. This study demonstrated that floating geoelectric methods can be a powerful tool for providing information (for example, identifying aquifer properties and locating areas of potential gains and losses in streams) in a more expedient and cost-efficient manner compared to traditional surface-water/groundwater exchange methodologies. Future studies could be designed to quantify the flow rates between the surface water and groundwater, as water exchanges can vary based on season, drought or flood conditions, and aquifer hydrologic conditions. Additional studies could also further explore the delineation between possible local and regional aquifer interactions.

This fact sheet is based on the following publication:

Ikard, S.J., Teeple, A.P., Payne, J.D., Stanton, G.P., and Banta, J.R., 2018, New insights on scale-dependent surface and groundwater exchange from a floating self-potential dipole: Journal of Environmental and Engineering Geophysics, v. 23 , no. 2 , p. 261-287, https://library.seg.org/doi/ abs/10.2113/JEEG23.2.261.

\section{References Cited}

Baker, E.T., 1995, Stratigraphic nomenclature and geologic sections of the Gulf Coastal Plain of Texas: U.S. Geological Survey Open File Report 94-461, 34 p., 8 pls.

George, P.G., Mace, R.E., and Petrossian, R., 2011, Aquifers of Texas: Texas Water Development Board Report 380, 182 p.

Griffiths, D.J., 1999, Introduction to electrodynamics (3d ed.): Upper Saddle River, N.J., Prentice Hall, 576 p.

Ikard, S.J., Teeple, A.P., Payne, J.D., Stanton, G.P., and Banta, J.R., 2017, $14.86 \mathrm{~km}$ profiles of the electric and self-potential fields measured in the lower Guadalupe River channel, Texas Interior Gulf Coastal Plain, September 2016: U.S. Geological Survey data release, https://doi.org/10.5066/F7CJ8CDH.

Nyquist, J.E., and Corry, C.E., 2002, Self-potential: The ugly duckling of environmental geophysics: The Leading Edge, v. 21, no. 5, p. 446-451. [Also available at https://doi. org/10.1190/1.1481251.]

Revil, A., Ahmed, A.S., and Jardani, A., 2017, Self-potential: A non-intrusive ground water flow sensor: Journal of Environmental and Engineering Geophysics, v. 22, p. 235-247. [Also available at https://doi.org/10.2113/ JEEG22.3.235.]

Reynolds, J.M., 1997, An introduction to applied and environmental geophysics: West Sussex, England, John Wiley \& Sons Ltd., 796 p.

\section{-By Scott J. Ikard, J. Ryan Banta, and Gregory P. Stanton}

For more information about this publication, contact

Director, Texas Water Science Center

U.S. Geological Survey

1505 Ferguson Lane

Austin, TX 78754-4501

For additional information visit https://www.usgs.gov/centers/tx-water.

Publishing support provided by Lafayette Publishing Service Center

Any use of trade, firm, or product names is for descriptive purposes only and does not imply endorsement by the U.S. Government. 